\title{
De GGD als spil in de Gezonde School-aanpak
}

\author{
Sabine Neppelenbroek · John Ekkelboom · Judith de Meij · Michaela Schonenberger
}

(C) The Author(s) 2020

Samenvatting Scholen die de Gezonde School-aanpak willen omarmen, kunnen een beroep doen op hun lokale Gezonde School-adviseur van de GGD. Deze adviseur geeft niet alleen adviezen voor en ondersteuning bij de transformatie tot een Gezonde School, maar brengt als spin in het web ook alle gewenste partners bijeen om gezamenlijk dat doel te bereiken. Alleen een integrale en structurele aanpak kan de Gezonde School op een school definitief waarborgen. Het thema Welbevinden komt daarbij steeds meer centraal te staan.

Trefwoorden gezondheid $\cdot$ preventie $\cdot$ school . wijkgerichte zorg · welzijn

\section{Municipal Public Health Services as key player in Healthy School approach}

Abstract Schools who wish to adopt the Healthy School approach, can make an appeal on the local Healthy School advisors of the municipal Public Health Services (in Dutch GGD'en). These advisors not only support schools to become a Healthy School, they are the key players in bringing all partners together to achieve that goal. Only by applying an integral and structural approach, an embedded Healthy School can be guaranteed. Wellbeing, as

S. Neppelenbroek $(\bowtie) \cdot$ M. Schonenberger

GGD GHOR Nederland, Gezonde School, Utrecht, Nederland

sneppelenbroek@ggdghor.nl

J. Ekkelboom

Nijmegen, Nederland

J. de Meij

GGD Amsterdam, Gezonde School, Amsterdam, Nederland one of the Healthy School themes, might become the cornerstone of the Healthy School in the future.

Keywords Health · Promotion · School · Municipal public health service $\cdot$ Wellbeing

\section{Inleiding}

In de Delftse woonwijk Voorhof zijn zes jaar geleden twee basisscholen gefuseerd en samen in een nieuw gebouw verdergegaan als de Parkschool. De huidige school telt ongeveer 160 leerlingen, van wie zo'n 95\% een migratieachtergrond heeft. Nico Nijenhuis, sinds 2016 de directeur, vertelt dat hij in het begin een hachelijke situatie aantrof. 'Het gedrag van de kinderen was abominabel. Diverse leerkrachten wilden weg omdat ze de spanning niet meer aankonden. Dat hebben we drastisch aangepakt. Overigens niet alleen voor de leerkrachten, maar ook voor de kinderen, die door dat slechte gedrag niet aan leren toekwamen. We hebben toen een kinderpsychiater ingeschakeld. Hij ging aan de slag met Echt Wel, een methode met duidelijke regels en een individuele benadering. Langzaamaan zagen we een positieve kentering, mede doordat we als Gezonde School naast de thema's Voeding en Bewegen \& Sport ook al met het thema Welbevinden bezig waren. Scoorden we voorheen heel laag bij de onderwijsinspectie, vorig jaar kregen we zelfs een dikke voldoende'.

Joline van Lier, die als Gezonde School (GS)-adviseur van de GGD Haaglanden onder andere de Parkschool onder haar hoede heeft, was ook nauw betrokken bij de verandering op die school. Die past volgens haar mooi binnen het thema Welbevinden van de Gezonde School (GS), een onderwerp waarover ze bijeenkomsten organiseert voor de gemeenten en samenwerkingspartners in de regio Haaglanden. De Parkschool vindt zij een prachtig voorbeeld van het 
positieve effect van de GS-aanpak. 'Op deze school, gelegen in een achterstandsbuurt, is enorm veel gezondheidswinst te behalen. Als GGD zijn we er uiteraard voor iedereen, maar ietsje extra voor degenen die ondersteuning het meest nodig hebben. Je wilt de kloof verkleinen in dit land. Dit betekent dat je als school niet eenmalig een les moet aanbieden over gezondheid, maar dat het GS-beleid continu aandacht moet krijgen door middel van een integrale aanpak via de pijlers educatie, signaleren, sociale en fysieke schoolomgeving, en beleid. Preventie is een proces van lange adem. Een school hoeft het niet alleen te doen, maar doet het samen met partners en de GS-adviseur als procesbegeleider en inhoudelijk adviseur.'

\section{Mindfulness}

Tijdens een wandeling door en rondom de Parkschool is de goede sfeer merkbaar. Nijenhuis, die tevens de GS-coördinator is van deze school, laat trots zien dat de leerlingen prettig met elkaar omgaan. Hij is ervan overtuigd dat dit vooral te danken is aan het Echt Welprogramma, de lessen mindfulness die geregeld worden gegeven en de aanstelling van een kindercoach. Niet alleen de onderlinge omgang is verbeterd, ook op het gebied van voeding en beweging is de laatste jaren volgens hem veel winst behaald. Het beleid daarop is fors veranderd, waarbij ook de ouders nauw betrokken zijn. Zo moeten de leerlingen een gezonde lunch mee naar school nemen, is alleen het drinken van water en melk toegestaan, mag een verjaardagstraktatie geen snoep bevatten en is er een actief beweegprogramma, bestaande uit schoolzwemmen, voetbal, schooljudo, sportevenementen en sporten bij buurtverenigingen.

Wat de school van de leerlingen verwacht, staat netjes omschreven. De school probeert die regels strikt na te leven. Als bijvoorbeeld een traktatie ongezond is, gaat die retour naar huis. Kinderen die zich tijdens een kerst- of sinterklaasfeest misdragen, worden apart genomen en mogen de viering dan gezamenlijk voortzetten onder toezicht van een leerkracht.

Nijenhuis vergelijkt het met een puppytraining, die er inmiddels toe heeft geleid dat de aparte behandeling niet meer nodig is. Hij heeft ervaren dat de GS-adviseur onontbeerlijk is. 'Joline draagt bij aan de bewustwording op school, signaleert problemen en wijst me de weg naar instanties die me kunnen helpen. Want eenvoudig is het niet. Ruim de helft van onze kinderen heeft trauma's als gevolg van oorlog of problemen thuis.'

Van Lier denkt dat het thema Welbevinden steeds belangrijker wordt binnen de Gezonde School. 'Als kinderen niet goed in hun vel zitten, is er immers geen goede basis voor een gezonde leefstijl en geen ruimte in het hoofd om te leren.'

Die mening is ook Margreet de Graaf toegedaan. Zij is directeur Publieke Gezondheid van de GGD Fryslân en portefeuillehouder Jeugd binnen de landelijke GGD GHOR Nederland. Binnen de GGD Fryslân is volgens haar mentaal welbevinden eveneens een belangrijk onderwerp. De mindfulnesslessen op de Parkschool beschouwt ze als een mooie aanzet daartoe. In Friesland wordt de Gezonde School breed gedragen. Die werd al in gang gezet voordat het landelijke ondersteuningsaanbod er was. De samenwerking tussen de jeugdverpleegkundigen en de gezondheidsbevorderaars als spil van de Gezonde School ziet de GGDdirecteur als een essentieel uitgangspunt. 'Zo maken we een verbinding tussen individuele onderzoeken en collectieve preventie op scholen. De Friese gemeenten vinden - net als de meeste gemeenten in Haaglanden - de GS-aanpak zo belangrijk dat ze naast het landelijke aanbod extra uren Gezonde School inkopen. We zien in de praktijk dat dit een enorme boost geeft.'

\section{GGD'en als hofleveranciers}

Gezien de integrale en onafhankelijke werkwijze, de kennis en kunde op het gebied van publieke gezondheid en de ver doorgevoerde netwerkfunctie van de GGD vinden De Graaf en Van Lier dat de GGD'en met recht de hofleveranciers genoemd mogen worden van de Gezonde School. Deze term werd enkele jaren geleden door de GGD GHOR Nederland geïntroduceerd. Vanwege die veelzijdige rol hebben de Friese gemeenten de GGD onlangs gevraagd om in navolging van het landelijke preventieakkoord de verschillende programma's in Friesland - zoals Kansrijke Start, Rookvrije Generatie, Nuchtere Fries voor alcoholmatiging en Nuchter over Gewicht om overgewicht bij kinderen tegen te gaan - vorm te geven in één Friese Preventie Aanpak.

De Graaf: 'De bedoeling is dat de levensloop en de fasen in mensenlevens als uitgangspunt worden genomen. De Gezonde School is een mooi middel om uitvoering te geven aan verschillende programma's. Het is goed dat preventieprogramma's voor scholen worden gebundeld, zodat er meer samenhang ontstaat. Dat is ook voor de scholen zelf veel prettiger, omdat die voor veel losse initiatieven worden benaderd.'

Ook Paul van Opdorp wijst op het belang van het verbinden van verschillende thema's en van een structurele samenwerking met de school. Hij is coördinator van het primair onderwijs-team Gezonde School van de Gemeente Amsterdam. 'We hebben ons de vragen gesteld: wat vinden wij eigenlijk een Gezonde School op het primair onderwijs? Is dat een school met veel aandacht voor voeding, bewegen en sport, maar waar wel nog veel gepest en gerookt wordt op het plein? Een Gezonde school is voor ons een school waar in de toekomst al die thema's op orde zijn. Dat betekent een langdurige samenwerking aangaan met een school. Natuurlijk doen we dat gefaseerd, aansluitend bij de behoeften van de school, volgens de GS-aanpak en samen met allerlei lokale preventiepartners.'

Vanaf september 2020 wil Van Opdorp met zijn team binnen het Amsterdamse primair onderwijs dan ook de bestaande losse programma's over voeding, 
beweging, seksualiteit en welbevinden verbinden onder de paraplu van Gezonde school. Tegelijkertijd proberen ze zo veel mogelijk datagestuurd te werken, waarbij ze kijken welke scholen de ondersteuning het hardst nodig hebben en welke thema's binnen een school prioriteit hebben. Daarvoor gebruiken ze cijfers vanuit onderwijs en uit de schoolgezondheidsprofielen van Jij en Je Gezondheid. 'Hiermee sluiten we met de Gezonde School mooi aan op ons gemeentelijk beleid, waarin kansengelijkheid hoog op de agenda staat. Een ander voorbeeld van datagestuurd werken is het gebruik van gegevens uit Hart \& Ziel, een sociaal-emotioneel leerlingvolgsysteem. Hiermee kunnen kinderen zowel op individueel als op groepsniveau worden gevolgd en is het mogelijk vroegtijdig passende ondersteuning te bieden.'

\section{Betere aansluiting basis- en voortgezet onderwijs}

Ouders spelen een belangrijke rol bij de GS-aanpak. Van Opdorp legt uit dat zij al bij de start worden betrokken, onder andere via de ouder- en de medezeggenschapsraad. 'Een school kan de GS-aanpak wel omhelzen, maar als de ouders bijvoorbeeld geen groenten, fruit en een gezonde lunch meegeven en roken op het plein, dan wordt het ook voor de school een moeilijke opgave. Je wilt de werelden thuis en op school zo veel mogelijk met elkaar verbinden. De school kan dan gemakkelijker veranderingen doorvoeren en je voorkomt dat het kind in een spagaat terechtkomt. Bovendien is het belangrijk dat het basis- en voortgezet onderwijs goed op elkaar aansluiten. Dat is een kwetsbare transitieperiode. Je wilt op het voortgezet onderwijs verder kunnen bouwen op de aanpak van het basisonderwijs.'

De GGD Gelderland-Zuid probeert die doorlopende lijn te verwezenlijken met een afdeling Gezond Leven. In deze regio van veertien gemeenten staat de collectieve gezondheidsbevordering voor alle inwoners centraal. De afgelopen jaren is daar een breed netwerk opgebouwd van scholen, gemeenten en partners - zoals sportorganisaties en verslavingszorg -, en ook de eigen GGD-afdelingen Jeugdgezondheidszorg en Algemene Gezondheidszorg. Iedere gemeente heeft te maken met minimaal een gezondheidsmakelaar School en Jeugd - in totaal zijn er dertien - die daar tevens als GS-adviseur fungeert voor alle scholen in zo'n gemeente.

Gerard Molleman, hoogleraar preventie aan het Radboudumc en voorheen manager van de afdeling Gezond Leven, vertelt dat deze infrastructuur ook gebruikt wordt om losse en ad-hocprojecten in onder te brengen. 'Er is landelijk en regionaal een groot aanbod op het gebied van gezondheid. Wij koppelen die projecten aan onze bestaande preventieve infrastructuur om meer samenhang te creëren. Dat vinden de scholen heel fijn. We merken dat dankzij deze sa- menhang en het bestaande netwerk de projecten en de benodigde subsidieaanvragen veel beter verlopen.'

\section{Gezonde School in de genen}

Bij de GGD'en Amsterdam, Haaglanden en Fryslân, en GGD Gelderland-Zuid worden gezondheidscijfers van leerlingen gebruikt om samen met scholen te kijken waar de accenten van de Gezonde School-aanpak moeten liggen. Zo heeft GGD Gelderland-Zuid ook voor het primair onderwijs een digitaal schoolrapport met gezondheidscijfers van leerlingen ontwikkeld (zie het artikel van Moerman en Dawson in dit themanummer [1]).

Geraldine Mulder, teammanager van de Gelderse gezondheidsmakelaars, geeft aan dat zo'n rapport het gesprek met de scholen vergemakkelijkt. Ze benadrukt echter dat niet alle scholen met de Gezonde School-aanpak meedoen. 'We proberen het uiteraard te stimuleren, maar als er geen interesse is, gaan we er niet aan trekken. Soms komt het niet gelegen of besteden ze uit zichzelf al veel aandacht aan gezondheid. Met $89 \%$ van de scholen in het primair en voortgezet onderwijs, en het mbo hebben we regelmatig tot intensief contact. Doordat we al zo'n tien jaar bezig zijn met de Gezonde School zie je dat scholen het in hun genen krijgen en daardoor minder ondersteuning nodig hebben. Inmiddels hebben we ervaring opgedaan met de Gezonde Kinderopvang en willen we een doorlopende lijn graag nog beter kunnen verwezenlijken.'

Dat het thema Welbevinden steeds belangrijker wordt, merkt ook Molleman. Als mooi voorbeeld binnen zijn eigen regio noemt hij het project SchoolsOut, dat de GGD jaren geleden samen met de gemeente Nijmegen en de LHBTI-beweging heeft opgezet. Dat gaat over sociale veiligheid en het vergroten van tolerantie rondom gender- en seksuele diversiteit, en wordt nu ook ingevoerd in de overige gemeenten. Molleman: 'Je kunt eindeloos lessen geven over hoe slecht roken is, dat je alcohol niet moet drinken of dat je vriendelijk moet zijn tegen homo's. Het is echter vooral belangrijk dat een kind ziet dat op school niet wordt gerookt of gedronken, er een gezonde kantine is, er veel aandacht is voor bewegen en dat het normaal is dat er bijvoorbeeld regenboogvlaggen hangen als er homoactiviteiten zijn.' Het mooie van de GSaanpak vindt hij dat het om collectieve gezondheidsbevordering gaat die een aanvulling vormt op de individuele aanpak die de jeugdgezondheidszorg en andere zorgpartijen op scholen leveren. 'Die aanpak werkt alleen met een goede infrastructuur waarin wij als GGD een belangrijke rol spelen om het onderwijs duurzaam, op maat en vooral in voldoende mate te kunnen ondersteunen. Dat is nu nog niet overal in het land het geval. Het zou mooi zijn als in de toekomst alle GGD'en de Gezonde School-aanpak met voldoende intensiteit uitvoeren.' 
Open Access This article is licensed under a Creative Commons Attribution 4.0 International License, which permits use, sharing, adaptation, distribution and reproduction in any medium or format, as long as you give appropriate credit to the original author(s) and the source, provide a link to the Creative Commons licence, and indicate if changes were made. The images or other third party material in this article are included in the article's Creative Commons licence, unless indicated otherwise in a credit line to the material. If material is not included in the article's Creative Commons licence and your intended use is not permitted by statutory regulation or exceeds the permitted use, you will need to obtain permission directly from the copyright holder. To view a copy of this licence, visit http://creativecommons.org/licenses/by/4.0/.

\section{Literatuur}

1. Moerman M, Dawson M. Het creëren van een schoolgezondheidsrapport over gezondheid, welzijn en leefstijl voor het basisonderwijs. Tijdschr Gezondheidswet. 2020. https://doi.org/10.1007/s12508-020-00273-9 